\title{
Enhancing Completion Rates in Public Day Secondary Schools in Kenya; the Role of Government Bursary Subsidy
}

\begin{tabular}{l}
\hline Githaka Mwangi ${ }^{1}$ (i) \\
Selpher K. Cheloti ${ }^{2}$ (D) \\
\hline${ }^{1,2}$ School of Education, South Eastern Kenya University, Kenya
\end{tabular}

\begin{abstract}
The purpose of the study was to investigate the influence of Government Bursaries on completion rates in public day secondary schools in Kitui County, Kenya. The journal is based on findings of a study conducted in 2017. The objectives of the study were; to investigate the influence of government bursaries on retention rates in day secondary schools in Kitui County; to assess the influence of government bursaries on dropout rates in day secondary schools in Kitui County; to assess the role government bursaries on retention rates in day secondary schools in ASAL areas of Kitui County; to assess the relationship between government bursaries and completion rates in day secondary schools in Kitui County. The study adopted descriptive survey research design. The study sample was 119 principals of public day secondary schools in Kitui County, 16 treasurers of Constituency Bursary Fund and one County Director of Education. Data was collected using a questionnaire, interview schedules and document review guide. Validity of the research instruments was ascertained through piloting and expert judgement. A test-re-test technique was used to assess reliability of the research instruments. The scores were correlated to get the co-efficient of stability using Spearman's coefficient of correlation and an instrument reliability value of 0.823 was obtained. Descriptive and inferential statistics was used to analyse data using Statistical Package for Social Science (SPSS). Chi-square $\left(\chi^{2}\right)$ was used to analyse hypothesis. The study found that government bursaries given to day secondary schools were not adequate to finance education expenses of the learner; the study further found that government bursaries increase retention rates in day public secondary schools; The study also found that government bursaries ensures learners in public day secondary schools in ASALs benefit from education. The study recommended that government should allocate more funds for bursaries in public day secondary schools. The study concluded that there is no consistency in disbursement of government bursaries in public day secondary schools.
\end{abstract}

Keywords: Government educational subsidies, Arid and semi-arid lands, Public day secondary schools, Retention rates.

\section{Contents}

1. Introduction

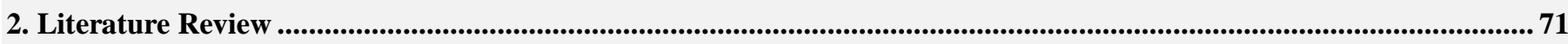

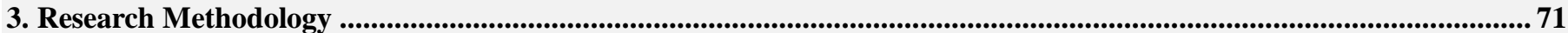

4. Theoretical Framework ....................................................................................................................................................................... 71

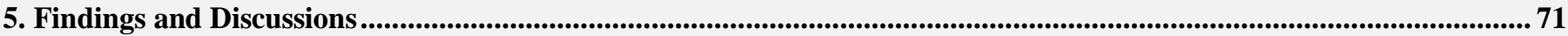

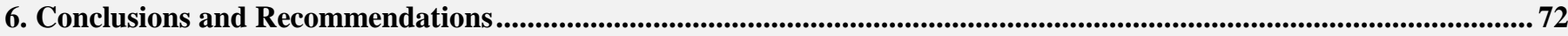

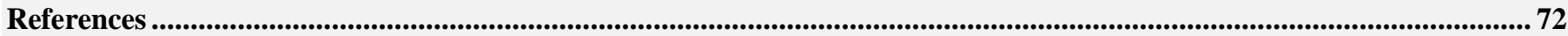

Citation | Githaka Mwangi; Selpher K. Cheloti (2017). Enhancing Completion Rates in Public Day Secondary Schools in Kenya; the Role of Government

Bursary Subsidy. Asian Journal of Education and Training, 3(1): 69-73.

$\operatorname{ISSN}(\mathbf{E})$ :

Licensed:

Contribution

Funding:

Competing Interests:

Transparency:

History:

Ethical:

Publisher:

\subsection{8/journal.522.2017.31.69.73 Crossref}

2519-5387

This work is licensed under a Creative Commons Attribution 3.0 License $(c)$ (E)

Both authors contributed to the conception and design of the study.

This study received no specific financial support.

The authors declare that they have no conflict of interests.

The authors confirm that the manuscript is an honest, accurate, and transparent account of the study was reported; that no vital features of the study have been omitted; and that any discrepancies from the study as planned have been explained. Received: 21 March 2017/ Revised: 10 April 2017/ Accepted: 17 April 2017/ Published: 21 April 2017

This study follows all ethical practices during writing. Asian Online Journal Publishing Group 


\section{Introduction}

Educational subsidy is an assistance given by the government as a policy to students in educational institutions in support of their studies and is regarded as being in the public interest (KIPPRA, 2008). The primary goal of public day secondary school educational subsidies is to promote school enrolment and reduce dropout rates by reducing tuition costs (Republic of Kenya, 2008).

Cameron (1997) explained that in many developed nations such as United States of America, Canada, Australia, France, Britain and Sweden among others, secondary education is available for all in public schools and is run and funded by the government. Cameron further commented that in some developing countries like Ghana, Nicaragua and Guetemala secondary education is compulsory. This has led to high completion rates (Cameron, 1997).

The United Kingdom abolished fees for state secondary schools through the Butler Act of 1944 and the compulsory school leaving ages was increased from 14 to 15. Lewin (2007) studies on Improving Access, Equity and Transitions in Education in Bangladesh, found that completion rates improved substantially in Bangladesh after the introduction of educational subsidies.

Study done by Lewin (2008) on Financing Education in Mauritius, explained that educational subsidies make secondary education more accessible. Muhindi (2012) noted that despite financial crisis and deficits, some governments in Sub-Saharan Africa (SSA) have recently extended free education from primary to include secondary schools. Rwanda and Uganda abolished lower secondary education fees in 2006 and 2007 respectively (Muhindi, 2012). The Government of Rwanda has a nine year basic education of which primary to lower secondary is free (UNESCO, 2007). This policy was implemented to ensure high completion rates (UNESCO, 2007).

The Government of Kenya subsidization of Education is motivated by the desire to increase transition and retention rates leading to low dropout rates hence high completion rates (Masimbwa, 2010). Educational subsidies include; Free Day Secondary School Education (FDSE), Constituency Development Fund (CDF) bursary, scholarships, teaching and learning materials and grants (RoK, 2008).

Subsidized secondary school education policy was introduced by the Government of Kenya in January 2008. The main objective was to make secondary school education accessible and affordable to all qualified students regardless their socio-economic background; in the long run improve the completion rates. A sum of Kshs 10265 was allocated to every student in public secondary school annually. The FDSE funds were to be later revised through government circular No. MOE.DSEC/5/17 of 2015 to Ksh. 12870 per student. The 1990 Jomtein World Conference on Education for All (EFA) encouraged governments all over the world to provide universal education to its citizens. In response to these resolutions, the Government of Kenya launched Free Day Secondary Education (FDSE) in 2008 as a strategy to make education accessible and affordable to many households in the country (Orodho, 2014). The launch of Free Day Secondary Education (FDSE) in 2008 was meant to address illiteracy, low quality education and low completion rates at the secondary level (RoK, 2005).

In 1993/1994 financial year Secondary Schools Bursary Scheme was introduced in Kenya to enhance access, ensure retention and increase completion rates (RoK, 2006). In line with government policy on decentralization, devolution and empowerment of communities, from the year 2003 the bursary scheme funds were channelled through Constituency Development Funds (CDF) (Ministry of Education, 2008). The bursary scheme was targeted to students from poor families, those in slum areas, those from pockets of poverty in high potential areas, districts in Arid and semi-arid lands (ASALs), orphans and the girl child (Onuko, 2012). Majority of beneficiaries of secondary schools bursary scheme were funded by CDF at 78 per cent. One major challenge facing provision of bursary was that students were not assured of continuous funding and that the disbursements were not in line with the school calendar year (Onuko, 2012)

The Ministry of Education, Science and Technology (MoES\&T) operates a bursary scheme at secondary school level as part of, and within the auspices of the Social Dimensions of Development Programme, targeting the poor and vulnerable households. The major objective of the scheme is to enhance access to, and ensure high quality secondary school education for all Kenyans. The philosophy behind the scheme was to translate into reality the idea that no child who qualifies for secondary education should be denied access due to inability to pay school fees (RoK, 2006).

The MoES\&T bursary allocation by province and by student during the 1999/2000 fiscal year show that allocations per student varied across the provinces. Four provinces got the largest amount above the national mean of Kshs. 318 per student. These were: Coast (Kshs. 569.40), North Eastern (Kshs. 508), Eastern (Kshs. 406.8), and Rift Valley (Kshs. 365). It is noted that these provinces are located in the economically marginal ASAL regions where most communities are poor and vulnerable. In contrast, the remaining provinces got lower allocations per student, and below the national mean: Nairobi (Kshs. 285.30), Nyanza (Kshs. 224.70), Central (Kshs. 219.70), and Western (Kshs. 205.50). These provinces represent the better-endowed areas, with high to medium agricultural and economic potential. As such, majority of households in these areas are assumed to have higher socio-economic status than their counterparts in ASAL regions. In awarding the bursary allocations, therefore, the MoES\&T incorporates mechanisms that take into consideration the ASAL limitations, among other vulnerable factors. Abuse of the bursary facility has been reported, with underserving cases awarded bursaries way above the amounts given to genuinely deserving students (RoK, 2006).

\subsection{Objectives of the study}

The study was guided by the following objectives

i. To investigate the influence of government bursaries on retention rates in day secondary schools in Kitui county Kenya.

ii. To assess the influence of government bursaries on access to education in ASALs in day secondary schools in Kitui county, Kenya. 


\section{Literature Review}

\subsection{Influence of Government Bursaries on Students' Completion Rates}

A bursary is a monetary award made by an institution to individuals or groups of people who have bursary capability from the school to help them pay education fees. Lewin (2008) found that completion rates improved substantially in Bangladesh after the introduction bursary scheme to secondary school students. Keith (2008) study in UK on Effect of Government Bursary on Transition and Completion rates found that it led to high transition and completion rates.

Muthoki (2015) study in Mtito-Andei Division Kibwezi Sub-County Makueni County found that government bursaries helped poor students' access secondary education leading to high retention rates, consequently leading to high students completion rates. The study used descriptive survey design. The target population was 2228 and the sample size was 228 respondents. It is on this basis this study sought to determine the extent to which government bursary influence completion rates in public day secondary schools in Kitui County.

A Study done by Onuko (2012) on Impact of Bursary Schemes on Retention of Students in Public Secondary Schools in Gem District, Kenya found that there were high retention rates in day secondary schools, this led to high completion rates. The study design was descriptive survey, the target population was 1947 and the sample size was 358 respondents. The study concentrated on the impact of all bursary schemes on retention of students in public secondary schools. It is on this basis this study sought to determine the extent to which government bursary influence completion rates in public day secondary schools in Kitui County.

Bursary funds for secondary schools are channelled through the Constituency Bursary Fund. This fund is meant to supplement the effort of FDSE to meet the financing gap of needy students. The fund was initially operated through the Ministry of Education and operationalized by the school Board of Management (BOM) at school level as Secondary Education Bursary Fund (SEBF) (MoE, 2008). Provision of bursary is one of several strategies used by government to ensure that disadvantaged children have equal opportunity in accessing education at all levels. This have led to high completion rates among the disadvantaged children (RoK, 2008).

There is also County Bursary Fund provided by the County Government through County Ministry of Education and Youth Affairs. These bursaries are meant to those students from low socio-economic background to improve on their completion rates. A Study done by Njau (2013) on Effect of Secondary Education Bursary Fund on Access and Retention of Students in Public Secondary Schools in Juja Constituency, Kiambu County Kenya found that Secondary Education Bursary has led high retention rates in day secondary schools, this led to high completion rates. Following the changes in the allocation mechanisms since 2003, claims of misallocation of bursary funds, double awards to one student in two schools, awards to students not enrolled in any school, as well as excessive patronage by members of parliament. These have negatively affected effectiveness of the funds (Muhindi, 2012).

\section{Research Methodology}

The study adopted descriptive survey research design. The target population consisted of 235 respondents. The sample consisted of 119 principals of public day secondary schools in Kitui County, 16 treasurers of Constituency Bursary Fund and one County Director of Education. Data was collected using a questionnaire, interview schedules and document review guide. Descriptive and inferential statistics was used to analyse data using Statistical Package for Social Science (SPSS). Chi-square $\left(\chi^{2}\right)$ was test used to analyse hypothesis.

\section{Theoretical Framework}

This study was anchored on the Classical Liberal Theory of Equal Opportunity by Jean-Jacques Rousseau (17121778). The theory states that all human beings are created equal and hence all the social institutions within a societal set up should promote this equality. In this context provision of equal opportunity to education is one way of promoting social equality in the society. The classical liberal theory was found to be relevant for this study because socio-economic background discriminates poor families who cannot afford to keep their children in school hence withdrawing them prematurely. The Government of Kenya introduced subsidized secondary education to give an equal opportunity in secondary education to all eligible secondary school students regardless of their socio-economic background (RoK, 2008).

\section{Findings and Discussions}

This study sought to investigate the role of government bursaries in enhancing completion rates in public day secondary schools in Kitui County. Principals were requested to indicate the influence of government bursaries on completion rate in public day secondary schools. Based on the principal's responses on the statement that government bursaries have increased student retention rates in public day secondary schools in Kitui County, the study found that provision of bursaries had increased completion rates in day secondary schools with $(71.4 \%)$ of the school principals agreeing with the statement. The study further found that government bursaries have ensured students in ASAL areas of Kitui County benefited in education and completed their secondary schools. The study also found that government bursaries have reduced student dropout rates in public day secondary schools in Kitui County with (72.4\%) of principals confirming the same. These results are shown in Table 1. 
Table-1. Findings of principals on influence of Government bursaries on completion rates in public day secondary schools

\begin{tabular}{|c|c|c|c|c|c|c|c|c|c|c|c|}
\hline \multirow[b]{2}{*}{ Statement } & \multicolumn{2}{|c|}{$\begin{array}{l}\text { Strongly } \\
\text { disagree }\end{array}$} & \multicolumn{2}{|c|}{ Disagree } & \multicolumn{2}{|c|}{ Undecided } & \multicolumn{2}{|c|}{ Agree } & \multicolumn{2}{|c|}{$\begin{array}{l}\text { Strongly } \\
\text { agree }\end{array}$} & \multirow[t]{2}{*}{$\begin{array}{l}\text { Mean } \\
\text { score }\end{array}$} \\
\hline & $\mathbf{F}$ & $\%$ & $\mathbf{F}$ & $\%$ & $\mathbf{F}$ & $\%$ & $\mathbf{F}$ & $\%$ & $\mathbf{F}$ & $\%$ & \\
\hline $\begin{array}{l}\text { Government bursaries have increased student } \\
\text { retention rates in public day secondary } \\
\text { schools in Kitui County. }\end{array}$ & 7 & 6.7 & 0 & 0.0 & 23 & 21.9 & 34 & 32.4 & 41 & 39.0 & 3.97 \\
\hline $\begin{array}{l}\text { Government bursaries have ensured students } \\
\text { in ASAL areas benefit in education in Kitui } \\
\text { County. }\end{array}$ & 2 & 1.9 & 0 & 0.0 & 8 & 7.6 & 47 & 44.8 & 48 & 45.7 & 4.32 \\
\hline $\begin{array}{l}\text { Government bursaries have reduced student } \\
\text { dropout rates in public day secondary schools } \\
\text { in Kitui County. }\end{array}$ & 6 & 5.7 & 1 & 1.0 & 5 & 4.8 & 48 & 45.7 & 45 & 42.9 & 4.19 \\
\hline $\begin{array}{l}\text { Government bursaries have } \\
\text { transition rate from public day secondary } \\
\text { schools to tertially institutions in Kitui } \\
\text { County. }\end{array}$ & 6 & 5.7 & 15 & 14.3 & 8 & 7.6 & 43 & 41.0 & 33 & 31.4 & 3.78 \\
\hline $\begin{array}{l}\text { There is no relationship between Government } \\
\text { bursaries and completion rates. }\end{array}$ & 59 & 56.2 & 3 & 2.9 & 12 & 11.4 & 26 & 24.8 & 5 & 4.8 & 2.19 \\
\hline
\end{tabular}

bursaries and completion rates.

Source: Field Data (2016)

Interviews with the Constituency Bursary Fund committee treasurers revealed that there are no records to track the beneficiaries of CDF bursaries. Regarding consistency in allocating the bursaries they indicated that they disburse the funds once per year in the month of December. They however indicated that funds are available to only guardians who are registered as voters in that particular constituency. Constituency Bursary Fund committee treasurers indicated that they are no application forms the beneficiary must present him or herself in person.

They further indicated that all form ones admitted in national schools automatically qualify for Ksh 10000 from the kitty regardless social or economic background. They however said that they are not able to track the beneficiaries of the fund because CDF treasurers do not keep records of the students who benefit from the funding. They also indicated that the office lack continuity because new officers are appointed every time there is an election and hence it is not possible to know the influence of CDF bursaries on completion rates. The CDF treasurers further indicated that disbursement of the funds is not consistent. Every year parents are to present themselves for funds allocation or fill an application form.

The study found that CDF bursary fund does not focus on needy students. It is disbursed to any parent with a student in secondary school who present him/herself to the committee and has affiliation to the constituency. This compromises its effectiveness.

The chi-square test $\left(\chi^{2}\right)$ of independence was used to test the hypothesis $\left(\mathrm{Ho}_{1)}\right.$ There is no statistically significant relationship between provisions of Government bursaries and completion rates in public day secondary Schools in Kitui County, Kenya.

The acceptable level of significance for the chi-square test $\left(\chi^{2}\right)$ test was 0.05 at 1 degree of freedom. Levels of significance found to be greater than 0.05 implied that the null hypothesis is rejected, on the contrary, if the level of significance was less than 0.05 then the null hypothesis was accepted. The results are as shown in Table 2.

Table-2. Chi-square test for the Influence of Government bursaries on completion rates

\begin{tabular}{l|l|l|l|l|l|l}
\hline Independent variable & Hypothesis & Chi- test & $\begin{array}{l}\text { Chi-sq. p } \\
\text { value }\end{array}$ & $\begin{array}{l}\text { Sig. } \\
\text { Value }\end{array}$ & Result & Decision \\
\hline Provisions of Government bursaries & $\mathrm{H}_{02}$ & 27.64 & 0.118 & 0.05 & $0.118>0.05$ & $\mathrm{H}_{02}:$ rejected \\
\hline
\end{tabular}

Source: Field Data (2016)

Table 2 shows that at 0.05 confidence level, the null $\left(\mathrm{H}_{01}\right)$ hypothesis yielded Pearson's P-value of 0.118 which is greater than 0.05 , hence, the null hypothesis was rejected. Consequently, its alternate hypothesis that there is statistically significant relationship between government bursaries and completion rates in public day secondary schools in Kitui County, Kenya, was accepted.

\section{Conclusions and Recommendations}

The study concluded that government bursaries have not been effective in ensuring retention of students in pubic day secondary schools. Regarding consistency the study concludes that there is no consistency in disbursement of government bursaries. The study also concludes that it was not possible to track the beneficiaries of the fund because CDF treasurers do not keep records of the students who benefit from the funding. Therefore the study recommended that government should increase funds allocated for bursaries in public day secondary schools. CDF Committees should improve on record keeping and tracking to ensure that needy students get bursaries.

\section{References}

Cameron, D.M., 1997. The framework for managing and financing post- secondary education in Canada. The forum papers, national forum on post-secondary education in Canada. Halifax, 1988: Institute for Research on Public Policy.

Keith, M.L., 2008. Four decades of educational planning: Retrospect and prospect. Paris: International Institute for Educational Planning.

KIPPRA, 2008. Public expenditure tracking of secondary education Bursary fund in Nairobi Province, Kenya. Retrieved from http://www.ipar.or.ke.

Lewin, K.M., 2007. Improving access, equity and transitions in education: Creating research Agenda. CREATE Pathways to Access Research Monograph, No. 1. Brighton: University of Sussex.

Lewin, K.M., 2008. Financing education in Mauritius: An analysis of cost and internal efficiency. Port Louis, Mauritius: Ministry of Education. 
Masimbwa, H.C., 2010. Cost- saving measures in enhancing efficiency in secondary schools in Kericho District, Kenya. Unpublished Thesis, Kenyatta University, Nairobi.

Ministry of Education, 2008. Guidelines for implementation of free secondary education. Nairobi: Government Printer.

Muhindi, D., 2012. Challenges facing the implementation of free day secondary education: A case study of Nyeri South District, Nyeri County in Kenya. Unpublished Master's Thesis, Kenyatta University, Nairobi.

Muthoki, M.M., 2015. Home based factors contributing to dropout of girls in mixed day secondary schools in Mtito-Andei division Kibwezi Sub-County Makueni County. Unpublished MEd Project, South Eastern Kenya University Kitui.

Njau, R.W., 2013. Effects of secondary education Bursary fund on access and rention of students in Public Secondary Schools in Juja Constituency, Kiambu County, Kenya. Unpublished MEd Thesis, Kenyatta University, Nairobi.

Onuko, A.J., 2012. Impact of bursary schemes on retention of student sin Public Secondary Schools in Gem District, Kenya. Unpublished MEd Thesis, University of Nairobi, Nairobi.

Orodho, A.J., 2014. Financing basic education: What are the equity and quality implication of free primary education and free day secondary education policies in Kenya? International Journal of Development Research, 4(3): 477-487. View at Google Scholar

RoK, 2005. Kenya education sector support programme (2005-2010). delivering quality education and training to all Kenyans. Nairobi: Ministry of Education, Science and Technology.

Republic of Kenya, 2008. Free secondary education programme. Nairobi: Government Printer.

RoK, 2006. Ministry of education strategic plan 2006- 2011. Nairobi: Government Press.

RoK, 2008. Free secondary education programme. Nairobi: Government Printer.

UNESCO, 2007. 2008 EFA global monitoring report. Education for All by 2015- Will we make it? Paris: UNESCO. World Bank. (2006). Expanding opportunities and building competencies for young people: A new agenda for secondary education. Washington DC: The World Bank. 